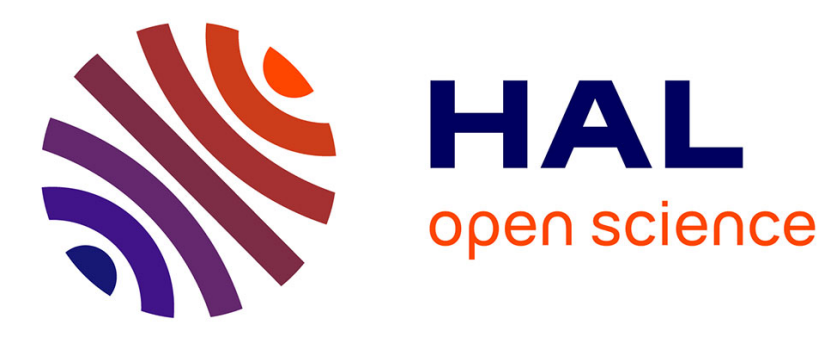

\title{
Analysing French Pension Reforms
}

Anne Lavigne

\section{To cite this version:}

Anne Lavigne. Analysing French Pension Reforms. Geneva Papers on Risk and Insurance - Issues and Practice, 2003, 28 (4), pp.727-733. halshs-00007670

\section{HAL Id: halshs-00007670 \\ https://shs.hal.science/halshs-00007670}

Submitted on 4 Jan 2006

HAL is a multi-disciplinary open access archive for the deposit and dissemination of scientific research documents, whether they are published or not. The documents may come from teaching and research institutions in France or abroad, or from public or private research centers.
L'archive ouverte pluridisciplinaire HAL, est destinée au dépôt et à la diffusion de documents scientifiques de niveau recherche, publiés ou non, émanant des établissements d'enseignement et de recherche français ou étrangers, des laboratoires publics ou privés. 


\section{Analysing French Pension Reforms}

Anne Lavigne *

June 2003

Abstract:

In 1982, the French socialist government lead by Pierre Mauroy reduced the legal age of retirement for both men and women. In 1993, the Balladur reform modified the pay-as-you-go basic private scheme. In March 1997, the Parliament enacted the Thomas Act that introduced retirement savings plan, but the law was never enforced because of the political change in June 1997, and was formally abrogated in 2002.

Amazingly there seems be a 10 years cycle in French pension system reforms since the French parliament started to examine a new pension reform presented by the French Prime minister JeanPierre Raffarin in June 2003. According to his defender, the project is the most comprehensive and the most ambitious since 1945. Our assessment is more critical: in fact, after a four-month round of negotiations with trade-unions and despite its impressive number of articles (81) the final project is milder than it originally was, with a parametric reform of the first pillar as its main component. This article aims at giving the main features of this reform. The first section presents the context of the reform. The second section is devoted to the main features of the reform, while section 3 gives a critical appraisal, underlines the remaining problems, and raises alternative relevant solutions.

Résumé:

En 1982, le gouvernement socialiste conduit par Pierre Mauroy réduisait l'âge légal de départ en retraite. En 1993, la réforme Balladur modifiait un certain nombre de paramètres du régime général de retraite par répartition. En mars 1997, le Parlement adoptait la loi Thomas introduisant des plans d'épargne retraite, mais la restait lettre morte faute de décret d'application, pour être formellement abrogée en 2002.

II semble ainsi exister un cycle de 10 ans dans les réformes des systèmes de retraites en France, puisque le Parlement a commencé à examiner un projet de loi de réformes des retraites en juin 2003. Selon son promoteur, le projet est le plus vaste et le plus ambitieux depuis la fin de la deuxième guerre mondiale. Notre évaluation est plus mitigée: malgré de longues négociations et un texte comportant un nombre impressionnant d'articles (81), le projet final est moins audacieux qu'initialement. Cet article entend donner les grands traits de la réforme. La première section en présente le contexte, la deuxième les traits principaux, tandis que la troisième en donne une évaluation critique, souligne les problèmes rémanents et suggère d'autres pistes de réformes.

JEL classification: J260

\footnotetext{
*Professor of Economics, Laboratoire d'économie d'Orléans, University of Orléans, France.
} 
In 1982, the French socialist government lead by Pierre Mauroy reduced the legal age of retirement for both men and women: since then men and women must be 60 years old to be eligible to full pension benefits. In 1993, the Balladur reform modified the pay-as-you-go basic private scheme: the contributory period was raised from 37,5 years to 40 years to get full benefits and the reference wage used to determine the pension benefits was modified to be computed on the best 25 years of career (instead of the best 10 years previously). In March 1997, the Parliament enacted the Thomas Act that introduced retirement savings plan, but the law was never enforced because of the political change in June 1997, and was formally abrogated in 2002.

Amazingly there seems be a 10 years cycle in French pension system reforms since the French parliament started to examine a new pension reform presented by the French Prime minister JeanPierre Raffarin in June 2003. According to his defender, the project is the most comprehensive and the most ambitious since 1945. Our assessment is more critical: in fact, after a four-month round of negotiations with trade-unions and despite its impressive number of articles (81) the final project is milder than it originally was, with a parametric reform of the first pillar as its main component. This article aims at giving the main features of this reform. The first section presents the context of the reform. The second section is devoted to the main features of the reform, while section 3 gives a critical appraisal, underlines the remaining problems, and raises alternative relevant solutions.

\section{The demographic, economic, financial and institutional context of the French pension reform}

According to demographic projections of the Institut National de la Statistique et des Etudes Economiques and the Conseil d'Orientation des Retraites, the next half-century will witness major changes in demographic trends:

- Population growth will progressively slow down: +0.32 \% average annual growth in 2001-2020, followed by a $+0.13 \%$ average in $2021-2040$.

- Population aged 60 and over will dramatically increase between 2005 and 2030, and the oldage dependency ratio will double over the same period.

- Oldest-age dependency ratio, measured by the number of people aged 85 and over relative to the number aged 60 and over, will experience a tremendous boom, due to the increase in lifeexpectancy at oldest ages. In 2000, the number of people aged 85 and over relative to the number aged 60 to 84 was 11.7, and it will reach 27,3 in 2050.

- As a consequence, the average age of people over 60 which is 72,4 years in 2003 , will be 75,5 in 2050.

How does France compare to other European countries? First of all, the French instantaneous fertility rate (1.81) is above the European average, and well above the Italian (1.29) and German (1.35) rates. Secondly, the old-age dependency ratios, measured by the number of people aged 65 and over relative to the number aged between 20 and 64, are comprised between $27 \%$ and $30 \%$ for France, Germany, Italy and Sweden in 2003. In 2050, they will reach $70 \%$ in Italy, $57 \%$ in France, and $45 \%$ in Sweden. Consequently, the French demography is less unfavourable than the one faced by its major neighbours.

Turning to active population, the Raffarin reform bets on a low unemployment rate for the fifty coming years. According to the Charpin Report (1999) and to the Conseil d'Orientation des Retraites (2002), a $6 \%$ unemployment rate is considered as a plausible assumption, which is optimistic when considering the past decade. Compared to other developed countries, France is characterised by a low 
employment rate, especially for older workers. The average age for entering the labour market was 18.6 in 1968 and 21.7 in 2002; the average ages for leaving the labour market were respectively 65 in 1968 and 59.3 in 2002. The consequence is a sharp decrease in the life-cycle working period, due to a longer period of education, a decrease in the legal retirement age in 1982, and the development of preretirement schemes in the 1980s.

According to the French government, these demographic and economic projections question the financial sustainability of the French pension system. If no reform were adopted, the expected deficit of aggregate pension regimes would amount to 50 billion of euros in 2020, representing 2 percentage points of annual GDP.

The French pension system has two main institutional characteristics: it relies on a pay-as-yougo basis for its first two pillars (basic general scheme and complementary compulsory schemes); and the first pillar is a heterogeneous collection of more than a hundred peculiar first-pillar retirement schemes introduced since 1945, with different techniques to acquire pension rights and to compute pensions, and different contribution periods (Lavigne, 2003). This complexity partly explains the recurrent difficulties in reforming the pension system in France.

\section{The main features of the Raffarin reform}

The main final objective of the Raffarin reform is to preserve the pay-as-you-go basis of the French pension system. A second and marginal in terms of law articles (4 out of 81 articles) objective is to promote funding in the third pillar. To reach the main final objective, the project aims at guarantying the financial sustainability of the pay-as-you-go pension system, through three intermediate targets: increasing labour force participation to ensure a high level of pensions; restoring the equality between the public and private schemes; introducing flexibility and degrees of freedom in the retirement choice. The main instruments are actuarially neutral incentives for the acquisition of pension rights and fiscal incentives for the funding side of the reform.

\subsection{Increase in labour force participation}

The French government has targeted an average level of pension equal to two thirds of the labour income for 2020 , and a minimum level of pension equal to $85 \%$ of the net minimum wage for a full career. To meet the first target, an increase in labour force participation and a longer contributory period are fostered.

The most significant innovation in the Raffarin reform is the introduction incentives to increase labour force participation at older ages, both for employers and employees.

- Stabilizing the ratio of expected retirement period relative to contribution period

A new special committee (Commission de garantie des retraites) is created to assess the evolution of demographic, economic and financial conditions and this committee has to deliver a report before the end of 2007. Unless the report indicates that the labour force participation of workers over 50 has significantly increased, or that the financial sustainability of pension schemes is not threatened, the contribution period will be increased by one quarter every year to take into account the expected increase of life expectancy at the age of 60 , starting from 2009. In 2012, the contribution period will thus be equal to 41 years and, if the Commission de garantie des retraites and the Conseil d'Orientation des Retraites estimate that the ratio of expected retirement period to contribution period has excessively increased, the contribution period may be increased by one quarter per year from 2016 until 2020. 
- Introducing a bonus for longer periods of contribution and a penalty for shorter periods of contribution

The Raffarin reform introduces a bonus of pension for a marginal quarter of contribution above 160 quarters both for private sector workers and civil servants. The amount of bonus will determined in a further decree but is expected to be equal to $0.75 \%$ per marginal quarter (i.e. $3 \%$ pension bonus per marginal year). Symmetrically, the same penalty will be imposed on early retirement (i.e. retirement for those who have not contributed during 40 years) for private sector workers and civil servants. This penalty already exists for workers of the private sector, amounts to $10 \%$ per missing contributory year, and will be progressively reduced to be equal to $5 \%$ in 2013 . This $5 \%$ penalty will be applied to civil servants starting in 2006 , with an upper limit of $25 \%$. No penalty will be charged for workers reaching the age of 65 , whatever the length of their contributory period.

- Imposing constraints on redundancies of older workers

At the age of 60 , an employee who has contributed during 160 quarters can be dismissed by his/her employer without redundancy indemnities. The project imposes that, even if the employee is eligible for pension at the age of 60 , the employer cannot dismiss the employee before his/her $65^{\text {th }}$ birthday if he/she is willing to stay in the job unless paying him/her redundancy indemnities.

- Limiting pre-retirement schemes to physically demanding jobs and restructuring firms

In the 1980s, many pre-retirement schemes have been set up by the successive governments. Basically, employers have fiscal and contributory incentives when they offer a pre-retirement scheme to their senior workers. The Raffarin reform aims at limiting fiscal incentives for pre-retirement schemes to two situations. The first one concerns physically demanding jobs, the second one applies to restructuring firms in financial distress. Otherwise the employer has to contribute at a special dissuasive rate $(23.85 \%)$, the contributions being accumulated in the pension reserve fund (see below).

- Enabling workers to continue to work while drawing pension

Progressive retirement is encouraged through the possibility of pursuing working activities (especially part-time jobs) while drawing pension. This possibility enables older workers to cumulate pension and new rights to pension.

\subsection{Reducing inequalities among contributors and pensioners}

Equal treatment of contributors whatever their occupation or their affiliation to a specific pension scheme is guaranteed by the pension reform.

\section{- Convergence of private and public schemes}

Since the Balladur reform enacted in 1993, workers in the private sector have to contribute during 40 years to be entitled to full pension benefits. The Raffarin reform progressively sets the contribution period equal to 40 years for the civil servants, instead of 37.5 years, until 2008. Also, for both private and public schemes, the pension will be proportional to the number of years of contribution:

Pension $=\alpha \cdot w_{r} \cdot \operatorname{Min}\left(1, \frac{d}{160}\right)$ 
where $d$ denotes the number of quarters of contribution, $w_{r}$ the reference wage, and $\alpha$ is a parameter positively related with $d$ and with the age at pension liquidation. Moreover the Raffarin reform introduces a clear rule of indexation of reference wages and pensions on prices. But there remain differences across private and public schemes. On the one hand, the reference wage is an average of the best 25 years of career in the private scheme and the average of the last six month (premiums excluded) in the public scheme 1 . On the other hand, the parameter $\alpha$ is equal at most to $50 \%$ in the first pillar private scheme and $75 \%$ in the public one (for full careers).

\section{- Early vs. late labour-market entry}

In order to take into account early labour-market entry (between 14 and 16 years old), the Raffarin reform enables workers who have contributed during a sufficient number of quarters (to be determined by a further decree) to be eligible to retirement starting from 56 years old (instead of 60 ). Symmetrically workers having completed university degrees will be enable to validate at most 3 years of studies as contributory years. This arrangement is designed to take into account late labour-market entry for highly skilled workers. Also all workers will be entitled to "buy back" at most 3 contributory years, i.e. to contribute on their current wage with no age limit even if they have not sufficiently worked to get pension rights at some periods of their career. This arrangement aims at taking into account disrupted careers.

\section{- multiple pension holders and self-employed}

Due to the existence of more than a hundred different pension schemes in France, some workers derive their pension rights from several regimes if they change job or position in their career. Under the current legislation this situation may be prejudicial to multiple-schemes affiliated workers since the computation of the reference wage is based on the best 25 contributory years in each scheme. The Raffarin reform homogenises the treatment of single and multiple pension holders. It also creates a compulsory complementary pension schemes for self-employed workers and professionals.

\section{- Survival benefits and family-related arrangements}

Under the current legislation survivors benefits and family-related arrangements are unequal with respect to gender and occupational status (wage-earners, self-employed and civil servants). To be entitled to survivor's benefits a widow must meet a series of legal requirements: being aged 55 and over, earning an income under the minimum wage, having being married at least two years and not being remarried. The Raffarin reform improves the situation of surviving spouses by treating men, women and occupational status equally and by simplifying the survivor's benefits arrangements. All the limits imposed on the surviving spouse are suppressed except the income limit which will take into account the new matrimonial situation.

Male and female civil servants will be treated equally as far as their credit for time raising children is concerned. Under the current legislation, a bonus of one contributory year per child is granted for women (that is women having contributed for 38 years and raised two children are eligible for full pension). The Raffarin reform introduces a contributory bonus of at most 3 years for child raising both for women and men if the parent takes a special leave for child raising. This arrangement will be enforced for children born or adopted starting from 2004.

\footnotetext{
${ }^{1}$ When first presented to the trade unions, the project set the reference wage on the last three years of career which was the main point of disagreement along with the inclusion of premiums in the reference wage.
} 


\subsection{Introducing funding}

The last part of the pension reform is devoted to third pillar pensions even if the word "pension fund" is never mentioned. It creates a new individual retirement savings product (plan d'épargne pour la retraite) subscribed individually or on an occupational basis. The management of funds will be operated by an associative structure in order to secure the invested funds. This retirement savings product will serve annuities as soon as the contributor is eligible for the first pillar pension. The fiscal incentive is based on the deduction of contributions from disposable income under a ceiling to be determined by a further decree. Moreover tax treatment of all existing retirement savings devices will be treated equally. The Plan Partenarial d'épargne salariale volontaire created in February 2001 by the preceding government is transformed in an explicit retirement saving plan which means that the invested sums will be converted in annuities or capital only when the affiliated is eligible to the first pillar pension (instead of a minimum 10-years investment under the current legislation, see Lavigne, 2003).

\section{Critical appraisal, remaining problems and alternative solutions}

This section gives a critical appraisal of the Raffarin reform ${ }^{2}$ underlying the remaining issues and the alternative solutions that could have been adopted.

\subsection{Method and content: much ado about nothing?}

The Raffarin reform has been criticised on two grounds. First of all, the social partners felt dissatisfied by Raffarin's method. When the Prime minister first announced his reform in February 2003, trade-unions and social partners expected an open and in-depth negotiation. They have been frustrated by their limited ability to amend the initial text which has rapidly leaded to a political struggle and massive strikes in the public sector (civil servants and other special schemes which are not concerned by the on-going reform).

Moreover despite its impressive length, the French pension reform project is not so ambitious, comprehensive and innovative as the Prime minister pretends it to be. Contrary to other European reforms, the Raffarin reform has not explicitly introduced notional accounts in the first pillar even if the notion of actuarial neutrality is present in two devices (the bonus/penalty of pension accruals with respect to extended/shortened contributory period and the increase in the contributory period with respect to life expectancy increases). But the reform is limited to the first-pillar main schemes (general basic scheme covering about $60 \%$ wage-earners, civil servants schemes, self-employed schemes and farmers schemes) leaving aside about several dozens of special schemes (railways monopoly, electricity monopoly, Banque de France...). It is a parametric reform that plays on the sole parameter of contributory period, leaving unchanged the legal retirement age, the contribution rates, and the replacement rates ${ }^{3}$. Besides, the second pillar which relies on two main compulsory complementary pay-as-you-go occupational schemes has not been modified at all despite its obvious flaws.

There is also a contradiction between the necessary budget deficit cutting imposed by the Stability and Growth Pact and the incentives given to increase labour force participation (see for example, the incentives given to civil servants to get part-time job at old ages or to stay longer in their jobs). Besides, the possibility of buying back contributory periods clearly gives disincentives to stay in the labour market at old ages.

\footnotetext{
2 This article has been completed on June 30th while the project was still discussed at the Assemblée nationale and had to be discussed at the Sénat which means that the project under review is subject to amendments.

3 Only the preamble of the law mentions a possible increase of contribution rates in the following years.
} 


\subsection{The burning issue of the special schemes}

Notwithstanding the flaunted willingness to reduce inequalities among contributors, there still remains an unequal treatment of income-earners. Many special retirement schemes have not been affected by the current reform, and if the law is literally interpreted, these schemes have to be reformed in a near future. And even if the civil servants pension scheme has the same contributory period as in the basic general scheme, there remain differences in reference wages and replacement ratios.

\subsection{Alternative solutions}

There is a slight hypocrisy in saying that the legal retirement age is not, and will not be, modified since the contributory period necessary to be eligible to full pension will increase along with life expectancy. The Raffarin reform by itself also keeps unchanged the contribution rates and the replacement rates which could have been used as a "parametric mix" of solutions.

The main difference between the French pension reform and other European reform is the marginal use of funding in public pension financing. As was mentioned above, the second pillar functions on a pay-as-you-go basis and the project is very allusive on the new retirement savings plans. There is a real taboo on pension funds in France, at least on the trade-unions side that has been reinforced by the Enron and WorldCom affairs. Nevertheless funding could have been instilled through the active use of the public pension reserve fund that has been created in 1999. This reserve fund could have been abounded by a special contribution on employers and employees. Some rough estimates suggest that an extra-contribution equal to $0.5 \%$ to $1.5 \%$ is sufficient to meet the transitory needs of the $2006-2020$ horizon.

\section{REFERENCES}

CHARPIN, J.M., 1999, L'avenir de nos retraites, Rapport au Premier Ministre. Paris: La Documentation Française.

CONSEIL D'ORIENTATION DES RETRAITES, 2001, Retraites, renouveler le contrat entre les générations. Paris: La Documentation Française.

LAVIGNE, A., 2003, "Pension Funds in France: Still a Dead End?", The Geneva Papers on Risk and Insurance, Issues and Practice, 28 (1), pp. 127-150. 